\title{
Plants Foraged by Apis mellifera adansonii Latreille in Southern Chad
}

\author{
Delphine Dongock Nguemo*, Pierre Marie Mapongmetsem, Mahamat Abdoulaye \\ Laboratory of Biodiversity and Sustainability Development, Department of Biological Sciences, \\ University of Ngaoundere, Ngaoundere, Cameroon \\ Email: *dndongock@yahoo.fr, ${ }^{*}$ ddongock@uni-ndere.cm, \\ piermapong@yahoo.fr, mahamatabdou307@yahoo.fr
}

Received 17 June 2016; accepted 12 August 2016; published 15 August 2016

Copyright (C) 2016 by authors and OALib.

This work is licensed under the Creative Commons Attribution International License (CC BY). http://creativecommons.org/licenses/by/4.0/

(c) (i) Open Access

\begin{abstract}
Melliferous plants of Chad are less known despite their diversity. The main objective of this study was to better assess the diversity of these plants. This work was carried out in the rainy of 2014 in the region of Guera. Direct observations of bees foraging during seasonal field trips were carried competed by interview of a total of 300 volunteers' beekeepers using a semi-structured questionnaire. A total of 52 melliferous plants distributed into 16 botanical families were identified. The most represented family in term of number of species was Mimosaceae (37.25\%) and the least was Tiliaceae $(01.96 \%)$. The biological distribution of the beeplants species revealed that trees $(54.90 \%)$ were the abundant type. The flower colour of melliferous plants was variable, with the white color $(23.52 \%)$ being dominant. The spontaneous species $(81.00 \%)$ were highly more frequent compared to the cultivated beeplants. Polliniferous plants $(60.0 \%)$ were more represented as compared to nectariferous plants $(\mathbf{4 0 \% )}$.
\end{abstract}

\section{Keywords}

Melliferous Plants, Apis mellifera, Biological Type, Southern Chad

Subject Areas: Plant Science

\section{Introduction}

The sustainable management of plant resources includes among other things a better knowledge of the resources and their rational exploitation. Melliferous plants are amongst these important resources. They are plants species from which bees extract substances, notably nectar, pollen and resin, for their food and other purposes [1]. Beeplants form part of vegetal resources with multiple virtues that has to be protected. They are playing a great role in the dynamics of ecosystems through pollinating insects [2].

\footnotetext{
${ }^{*}$ Corresponding author.
} 
The degree of selectivity of bees' vis-à-vis flora seems to be influenced not only by floral morphology, plant phenology and climatic factors, but also by the length of their tongue [3]. Hive products reflect in quantity and quality the nature of the plants foraged [1] [4] [5]. Beekeeping is an effective means to generate monetary incomes that support the livelihood of rural communities [6]. Numerous studies have demonstrated the economic value of honeybees to the agricultural industry of the world.

In Africa, especially areas in south of Sahara, this phenomenon is not fully known because of the lack of scientific studies [6]. Therefore the study of melliferous plants is of great interest. This knowledge constitutes the basis for the objective evaluation of the productivity of bee's products in different regions [1]. Knowledge about how extensively, frequently and/or intensively bee plants are exploited is of great interest. Knowing which melliferous plant is exploited by Apis helps to assess honey origin then the traceability. The knowledge of plants visited by bees is essential in guiding prospective for beekeepers in the choice of suitable sites for locating apiaries. It is also essential in the identification of crops that may benefit from pollination by honeybees [3] [7]. This can also give valuable information about evolution of the ecosystem and environment [3].

A lot of studies related to the apiculture practice and honey have been carried out in the developed countries, where melliferous plants, biochemical and pollen composition of honey and floral calendar are better known. On the contrary in Africa, particularly in Sub-Saharan Africa, works related to the knowledge of melliferous plants are recent. Most of the studies are limited essentially to the inventory of beeplants, pollen analysis of honey and also beeplants relationship [1] [4] [5] [7]-[22]. There is still limited information on melliferous plants of Chad [3] [23]. A better knowledge on the inventory of plants foraged by bees is of importance for an efficient and sustainable management. The knowledge of plants visited by bees is essential in guiding prospective beekeepers in the choice of suitable sites for locating apiaries. It is also essential in the identification of crops that may benefit from pollination by honeybees. The objective of this study was to make an inventory of the bee floral resources in the Sudano-Sahalian zone of Southern Chad with a view of preparing a checklist of melliferous plants.

\section{Material and Method}

\subsection{Presentation of the Study Zone}

The region of Guéra ( $\mathrm{LN} 09^{\circ} 32^{\prime}-13^{\circ} 00^{\prime}$ and $\left.\mathrm{LE} 17^{\circ} 00^{\prime}-20^{\circ} 00^{\prime}\right)$, is a geographic transition zone between pastoral Sahelian and the agricultural Sudanian zones (Figure 1). It has a surface area of $61,280 \mathrm{~km}^{2}$ with nearly 10 habitants per km scare [24]. The climate is of the Sudano-Sahelian type with the annual rainfall between 300 to $900 \mathrm{~mm} /$ year. The vegetation subjected to rainfall gradient and is woody or clear savanna according to latitude and relief. The hydrography is made up of some few streams which favor the circulation of underground water. The average annual temperature is $29.5^{\circ} \mathrm{C}$ (minimum in December-January $18^{\circ} \mathrm{C}$ and maximum in March $40^{\circ} \mathrm{C}$ ). The natural vegetation is Acacia woody Savannah. The major ethnic group in this region is Hadjaraï. The economy of this region is based on cereals (sorghum and maize), groundnuts and sesames production by women [24]. Traditional extensive apiculture is practiced.

\subsection{Determination and Identification of Honeybee Plants}

Direct observations during Periodical field trips in rainy and dry seasons in 2014, between 6 a.m. and 6 p.m. were carried out. Plants whose flowers were foraged by workers bee for at least two minutes were considered as honeybee plants. Already known as melliferous plants in the literature were recorded, unknown and unfamiliar plants were identified using botanical field guides [25]-[27]. All the identified plants were classified according to botanic characteristics (biological type, flower color, degree of domestication). Some of the plants were photographed with a digital camera.

\subsection{Statistical Analysis}

The quantitative data collected were treated using variance analysis with the aid of Statgraphic plus version 5.0.

\section{Results and Discussion}

\subsection{Spectrum of Melliferous Plants of the Guera Region}

A total of 52 melliferous plants divided into 16 botanic families were identified in the Guera region (Table 1; Figures 2-7). Mimosaceae with $37.25 \%$ of the bee plants indentified, was the most represented family followed 
Table 1. Distribution of families and species of melliferous plants by biological types, flower's colors, food collected and status of domestication of the Guera region.

\begin{tabular}{|c|c|c|c|c|c|}
\hline Family & Species & $\begin{array}{c}\text { Biological } \\
\text { type }\end{array}$ & Flower color & $\begin{array}{c}\text { Food } \\
\text { collected }\end{array}$ & $\begin{array}{c}\text { Domestication } \\
\text { Status }\end{array}$ \\
\hline \multirow{3}{*}{ Anacardiaceae } & Lannea humilis (Oliv.) Engl. & Shrub & Green/greenish & Nectar/ Pollen & Natural \\
\hline & Mangifera indica L. & Tree & Orange yellow & Nectar & Cultivated/Natural \\
\hline & Sclerocarya birrea (A. Rich) Hochst & Tree & Red/reddish & - & Natural \\
\hline \multirow[t]{2}{*}{ Balanitaceae } & Balanites aegyptiaca (L.) Del. & Tree & Yellowish green & Pollen & Natural \\
\hline & Delonix regia (Boj.) Raf. & Tree & Red/reddish & Nectar/Pollen & Natural \\
\hline \multirow[t]{4}{*}{ Caesalpiniaceae } & Tamarindus indica L. & Tree & Yellow & - & Natural \\
\hline & Isoberlinia doka Craib et Stapf & Tree & White/whitish & - & Natural \\
\hline & Anogeissus leiocarpus (DC.) Guill. et Perr. & Tree & yellow & - & Natural \\
\hline & Combretum collinum Fresen & shrub & Yellow & Nectar & Natural \\
\hline \multirow[t]{3}{*}{ Combretaceae } & Combretum glutinosum Perr. ex DC. & Tree & Yellow & Nectar & Natural \\
\hline & Guiera senegalensis J. F. Gmel. & Shrub & Yellow & Nectar & Natural \\
\hline & Terminalia schimperiana Hochst. & Tree & Yellow & - & Natural \\
\hline Cucurbitaceae & Cucumis sativus L. & small tree & Yellow & Nectar/Pollen & Cultivated \\
\hline \multirow[t]{4}{*}{ Euphorbiaceae } & Jatropha curcas L. & Tree & Yellow & Pollen & Natural \\
\hline & Jatropha gossypiifolia L. & Shrub & Green/greenish & Pollen & Natural \\
\hline & Manihot esculenta L. & small tree & Green/greenish & - & Cultivated \\
\hline & Dalbergia sissoo Roxb. & Tree & White/whitish & - & Natural \\
\hline Fabaceae & Arachis hypogea L. & Herb & Yellow & Ne, Po & Cultivated \\
\hline Malvaceae & Hibiscus sabdariffa Linn & Herb & Yellow & Pollen & Cultivated \\
\hline \multirow{3}{*}{ Meliaceae } & Azadirachta indica A. Juss. & Tree & White/whitish & - & Natural \\
\hline & Khaya senegalensis (Desr.) A. Juss. & Tree & White/whitish & Nectar & Natural \\
\hline & Acacia ataxacantha DC. & Shrub & White/whitish & Nectar & Natural \\
\hline \multirow{18}{*}{ Mimosaceae } & Acacia dudgeoni Craib ex Hall & Shrub & White/whitish & Pollen & Natural \\
\hline & Acacia erythrocalyx Brenan & Shrub & White/whitish & Pollen & Natural \\
\hline & Acacia gerrardii Benth. & Shrub & White/whitish & Pollen & Natural \\
\hline & Acacia gourmaensis A. Chev. & Shrub & White/whitish & Pollen & Natural \\
\hline & Acacia hockii De Wild. & Tree & Yellow & Pollen & Natural \\
\hline & Acacia macrostachya Reichenb. ex DC. & Tree & Yellow & Pollen & Natural \\
\hline & Acacia mellifera (Vahl) Benth. & Tree & White/whitish & Pollen & Natural \\
\hline & Acacia nilotica (L.) Wild. Ex Del. & Tree & Yellow & Nectar & Natural \\
\hline & Acacia senegal (L) Willd & Tree & Yellow & Pollen & Natural \\
\hline & Acacia seyal Del & Tree & Yellow & Nectar & Natural \\
\hline & Acacia sieberiana DC & Tree & Yellow & Nectar & Natural \\
\hline & Acacia tortilis subsp. Raddiana (Savi) Brenan & Tree & White/whitish & Pollen & Natural \\
\hline & Albiziaadianthifolia (Schumach.) W.F. Wight & Tree & White/whitish & Pollen & Natural \\
\hline & Entada abyssinica Steud. Ex A. Rich. & Shrub & White/whitish & Pollen & Natural \\
\hline & Faidherbia albida (Del.) Chev. & Tree & White/whitish & Pollen & Natural \\
\hline & Mimosa invisa C. Martius ex Colla & Herb & Red/reddish & Nectar/ Pollen & Natural \\
\hline & Prosopis africana (Guill. Et Perr.) Taub. & Tree & White/whitish & - & Natural \\
\hline & Prosopis juliflora (Sw.) DC. & Tree & Yellow & - & Natural \\
\hline Olacaceae & Ximenia Americana L. & Shrub & White/whitish & - & Natural \\
\hline
\end{tabular}




\begin{tabular}{cccccc} 
Continued & \multicolumn{1}{c}{} & & \\
\hline \multirow{2}{*}{ Poaceae } & Pennisetum glaucum (L.) R.Br. & Herb & Yellow & - & Cultivated \\
& Sorghum bicolor (L.) Moen & Herb & Yellow & - & Cultivated \\
Punicaceae & Zea mays L & Herb & Yellow & - & Cultivated \\
& Punica granatum L. & Shrub & Red/reddish & - & Natural \\
Rhamnaceae & Ziziphus abyssinica Hochst. ex A. Rich. & Shrub & White/whitish & Pollen & Natural \\
& Ziziphus mauritiana Lam. & Shrub & Yellow & Pollen & Natural \\
& Ziziphus mucronata Willd. & Shrub & Yellow & Pollen & Natural \\
Rutaceae & Ziziphusspina-christi (L.) Desf. & Shrub & Yellow & Pollen & Natural \\
& Citrus aurantifolia (Christm.) Swingle & Shrub & White whitish & - & Cultivated \\
Tilliaceae & Citrus limon (L.) Burm. f. & Shrub & White/whitish & - & Cultivated \\
\hline
\end{tabular}

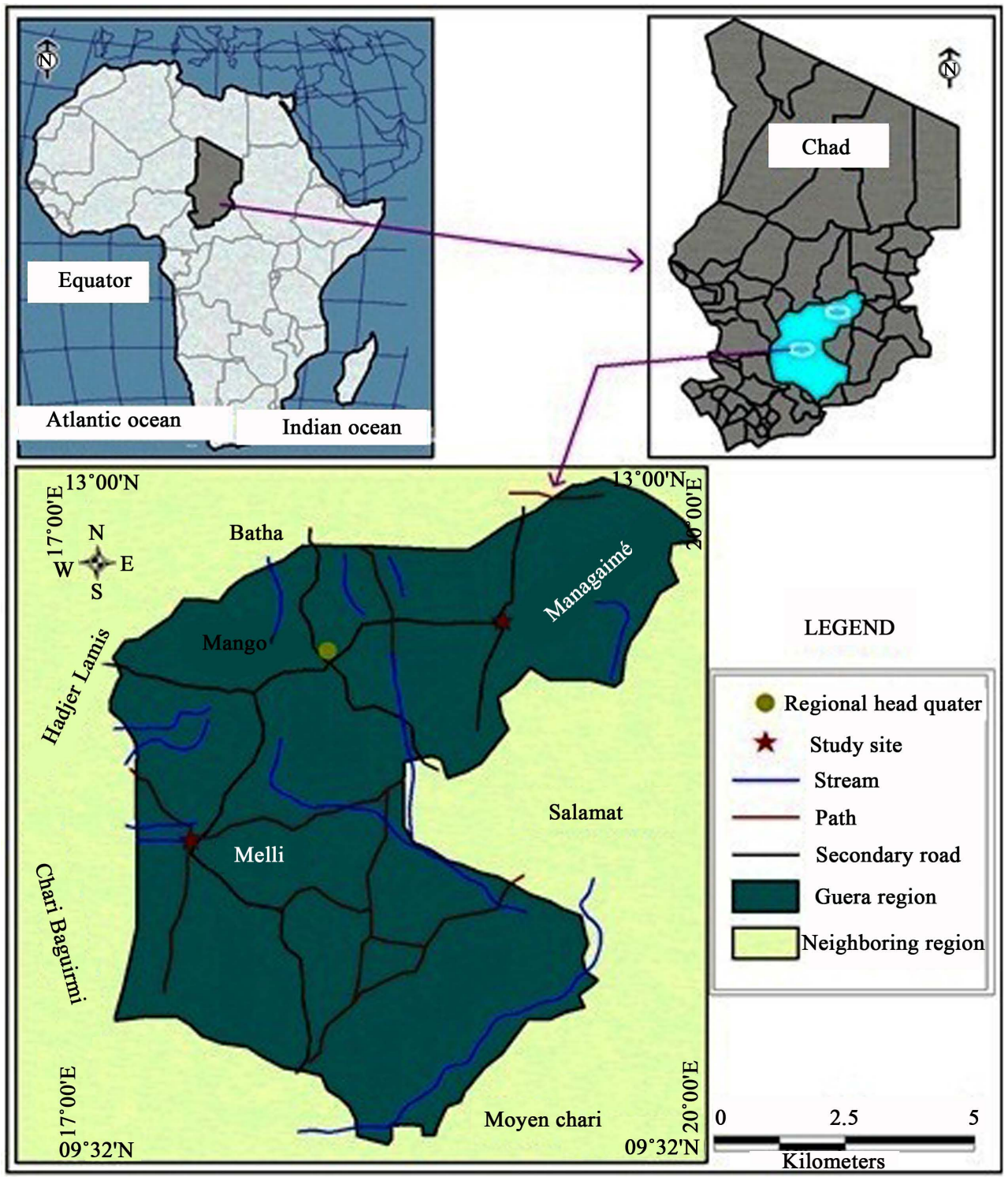

Source: CNAR 2003

Adapation Detabe: O 2013

Figure 1. Map of zone of study. 


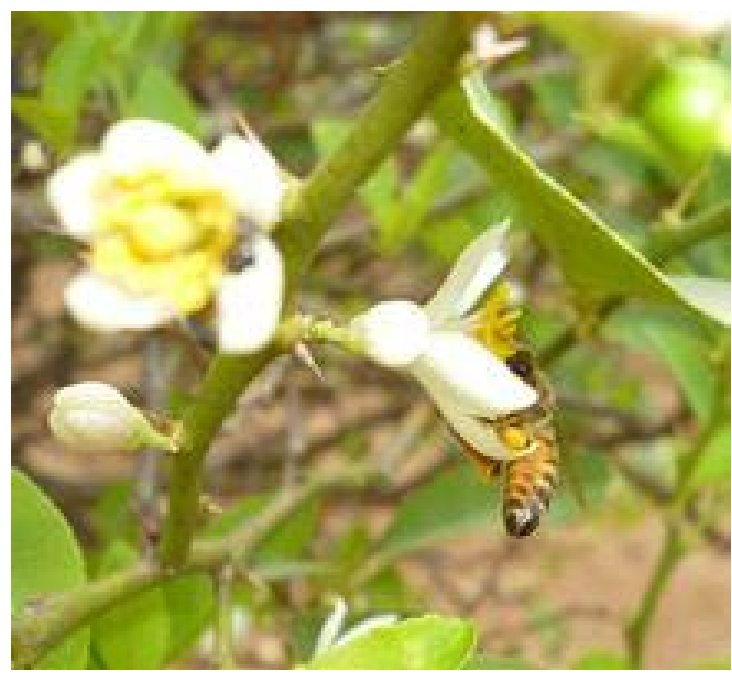

Figure 2. Citrus aurantifolia (Christm.) Swingle.

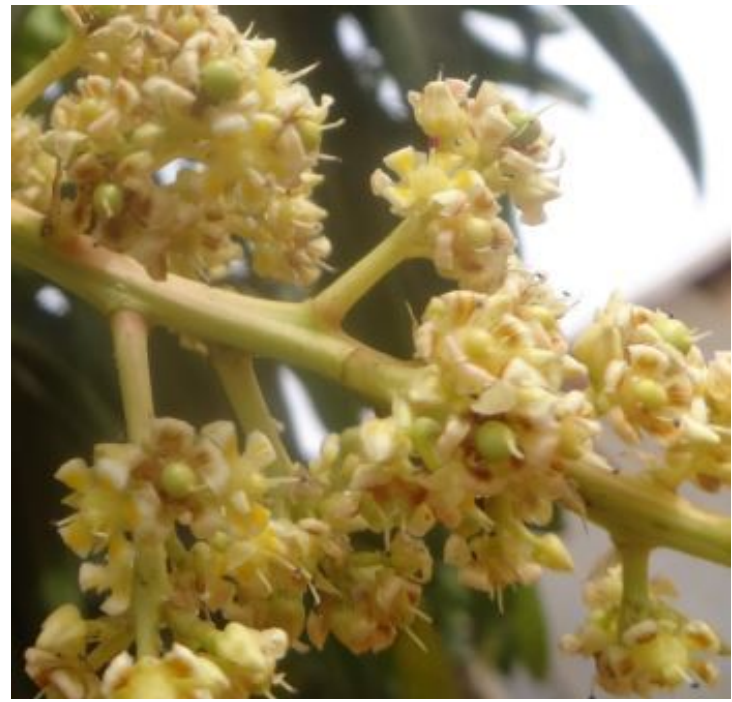

Figure 3. Mangifera indica L.

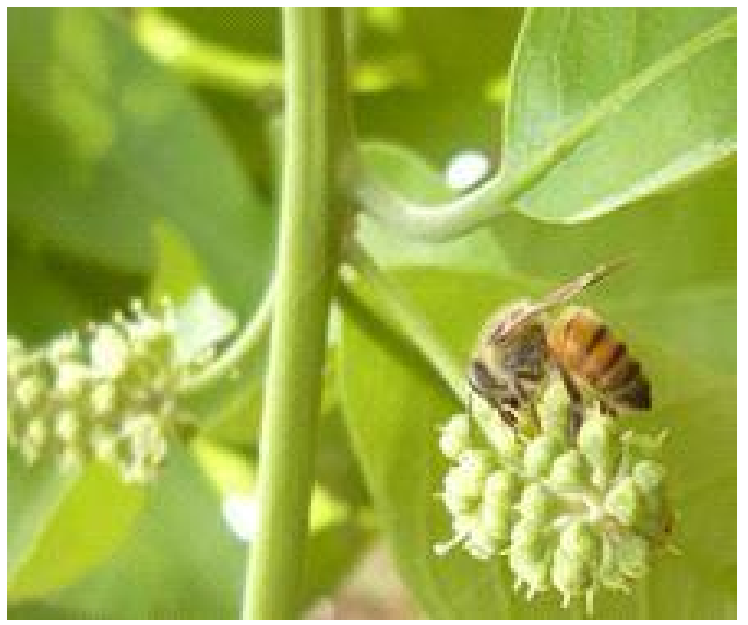

Figure 4. Combretum collinum Fresen. 


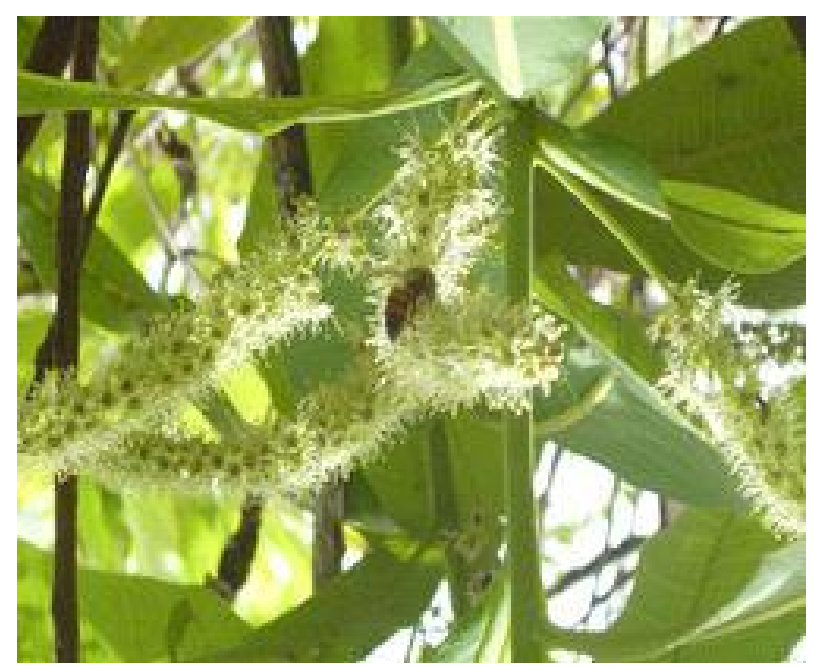

Figure 5. Terminalia schimperiana Hochst.

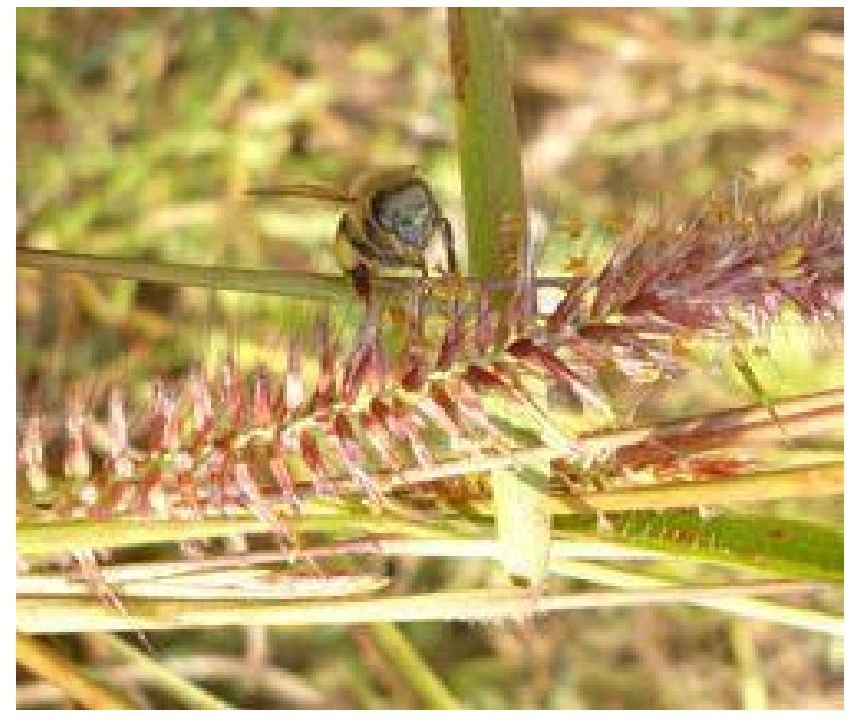

Figure 6. Pennisetum glaucum (L.) R. Br.

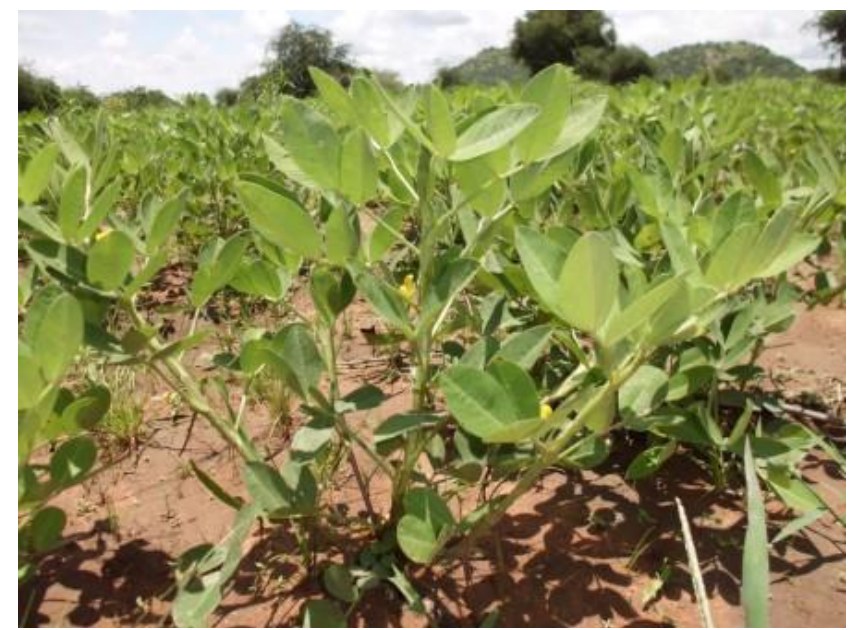

Figure 7. Arachis hypogea L. 
by Combretaceae and Poaceae (families repectively $07.84 \%$ and $05.88 \%$ of the beeplant species (Figure 8 ), while Balanitaceae, Cucurbitaceae, Malvaceae, Oleacea, Punicaceae and Tiliaceae where the least represented families with only one species. Acacia is the most frequent genera followed by Ziziphus.

In the savannah of north East Nigeria, Fabaceae and Combretaceae are families with highest number of melliferous species [5]. The number of melliferous plants identified is less than those collected in the other ecosystems, especially by Dukku [5] in the savanna zone of north East Nigeria that identified 61 species regrouped into 49 genus and 25 families. Among the fourth genera predominant (Acacia, Combretum, Ziziphus and Eucalyptus) in the north East of Nigeria, two were also frequently foraged by bees in our zone. In that same zone, Fabaceae and Combretaceae are the families with the highest number of plant species. In Burkina Faso, Sawadogo and Guinko [28] and in Côte d'Ivoire, Coulibaly et al. [29] identified respectively 118 (19 families) and 121 (45 families) bee plants. The genera with the highest number of species were Albizia and Ficus in Côte d'Ivoire. The most diversified families were Caesalpiniaceae, Mimosaceae, Euphorbiaceae, Rubiaceae and Fabaceae. The work of Bakenga et al. [13], in Bukavu and its surroundings in South-Kivu in the East of the Democratic Republic of Congo noted 147 beeplants where the most represented families were Asteraceae, Fabaceae, Solanaceae, Caesalpiniaceae, Lamiaceae and Malvaceae. In the West of Cameroon, 78 species were registered by Dongock Nguemo et al. [1], the most represented families were Asteraceae, Solanaceae and Euphorbiaceae. Meanwhile, the 51 melliferous plants collected were higher than those noted in the Western Chad where 25 species foraged by bees were reported by Gadbin [23]. Contrarily, it is Caesalpiniaceae that was the most frequent. Nonetheless 64 species registered in the Sudano-guinean of Togo by Aloma [30] were comparable to our results in the Guéra region. Globally, according to Lobreau-Callen and Damblon [3] in the Tropical region, as flowering plants were highly diversified and abundant, bees are very selective and forage the most attractive species near hives as such as spend less energy in their activity. They prefer very ornate foliage near the hives where they search the greatest suppliers of nectar among preferably species.

\subsection{Botanical Type of Melliferous Plants}

Honey of Guera region is divided in four biological types: trees, shrubs, small trees and herbaceous plants (Table 1). Trees are the most dominant (54.90\%) and the least abundant was represented by small trees (3.92\%). The analysis of variance indicates that there exists a significance difference between biological types $(P<0.05)$.

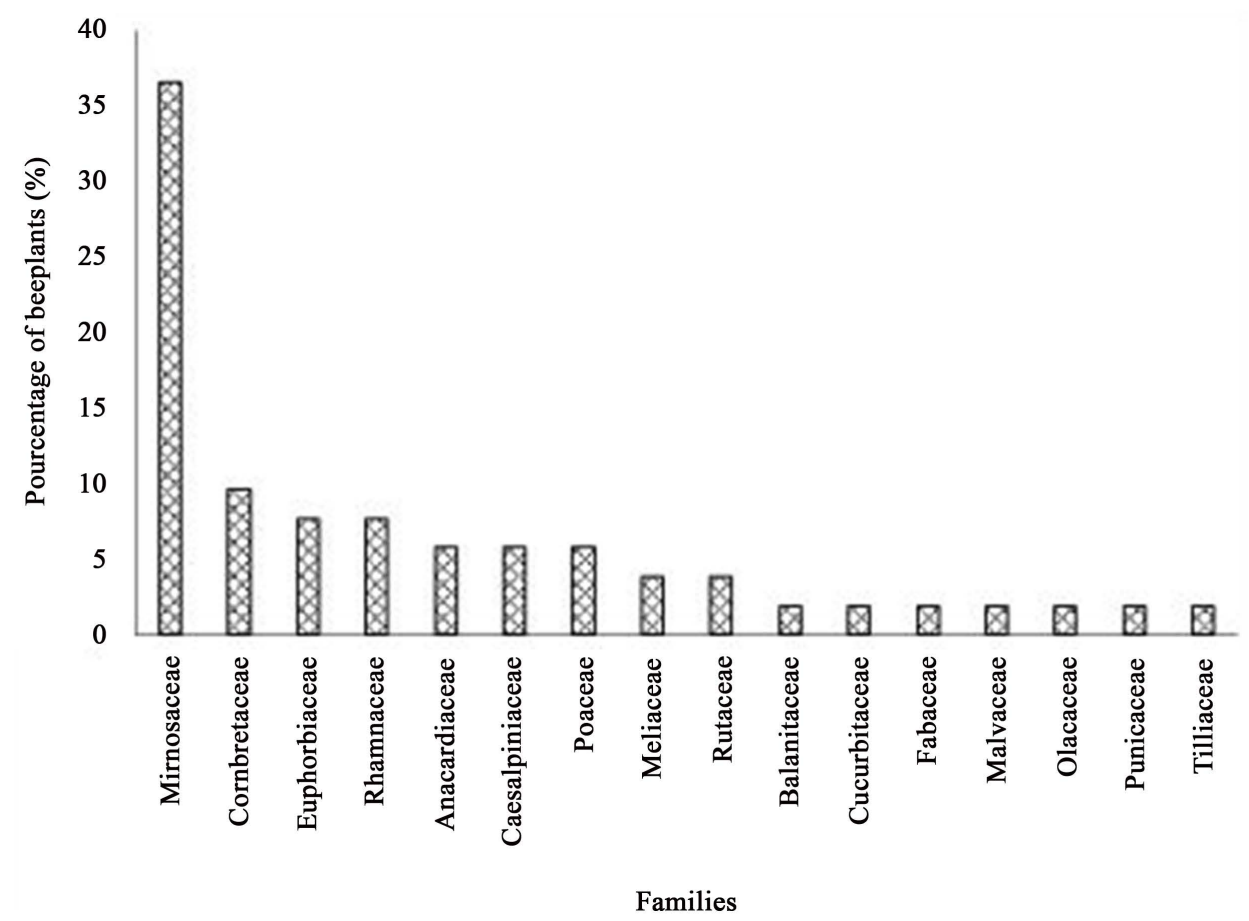

Figure 8. Distribution of families of melliferous plants. 
In the western highlands of Cameroon [1], also in Bukavu and its surrounding South Kivu in the Eastern Democratic Republic of Congo [13], in Burkina Faso [28], it is rather herbaceous that were dominants. However, in the Sudano-Guinean zone of West Cameroon [4] and the Sudanian savanna area of North Eastern of Nigeria [5], trees are predominant. Lobreau-Callen and Damblon [3] report that in the woody savannas at gallery forests proximity in Côte d'Ivoire and Nigeria, bees forage mostly on trees. On the other hand in the semi-arid area of Sudanian savannah, bees appear less selective because they forage at all plant strata. In the woody savanna of Cote d'Ivoire nearby galleries forest, in Nigeria and the Sudanian woody savanna, bees forage practically only trees. Lobreau-Callen and Damblon [3] specify that in the rainy season, bees are very selective and in priority exploit the flowering trees and shrubs, while in areas where grassland occupies a vast surface, herbaceous are more numerous. The biological type foraged by Apis mellifera adansonii varies with climate, season, morphological diversity and foraging behaviour.

\subsection{Flowers Colors of Melliferous Plants}

Flower color is important feature for bees and other insects. Bees are highly visual insects. Eight colors of flower were observed. The diversity of flower can be explain by the experienced of bees in that region. Gumbert [31] indicate that inexperienced bees are known to have strong colour preferences. The white color is statistically $(P<0.05)$ the most frequent $(23.52 \%)$ in the bee flora of the region; the greenish color is the least represented (3.92\%). These results are in accordance with those obtained in the highlands of western Cameroon and in the Sudano-Guinean zone of West for the dominant melliferous plants, where the white flowers color were more dominant [1] [4]. It does not confirm the observations of Mbofung et al. [32] on plants visited by insects at Campo in the South Cameroon where it is the yellow color that is the most visited. Bakenga et al. [13] show that melliferous plants of Bukavu in the Democratic Republic of Congo present blue, beige, red, purple and pink as common color flower. Fægri and Van der Pijl [33] in such observations, describing the floral colours of melittophilous flowers as being mostly blue or yellow and this led to the concept of a flower syndrome for bee pollination. Observations made in the field among flower varieties differing in nectar content, bees chose among them according to the proportion of reward rather than by their colour [34].

\subsection{Food Collected on Melliferous Plants by Bees}

Bees need diverse pollen and nectar sources for balanced diet. Polliniferous plants (60.0\%) were statistically ( $P$ $<0.05$ ) highly represented compared to nectariferous plants (40.0\%). Only five of these plants (Lannea humilis, Delonix regia, Cucumis sativus, Arachis hypogea and Mimosa invisa) provide both pollen and nectar to bees. These results were in accordance with those of Dongock et al. [1] in the Sudano-Guinean zone of West Cameroon. Contrary to our work, Bakenga et al. [13] noted that the plants visited by bees for nectar were well represented and constitute more than two thirds (45.6\%) of the beeplants studied in Bukavu. Nectariferous plants exclusively (25.0\%) have a higher proportion than in our results. Similarly plants visited for both pollen and nectar are less frequent (4.1\%) at Bukavu [13]. However, in relation to our study zone, this represents almost a third of melliferous plants identified.

\subsection{Domestication Status of Melliferous Plants}

Concerning the domestication status of bee plants in Chad, both spontaneous and cultivated plants were identified. The spontaneous species were statistical $(P<0.05)$ the most frequent $(81.0 \%)$ compared to the cultivated species (19.0\%). These results are in agreement with those of Dongock et al. [1] [4] in the highlands of western Cameroon and in the Sudano-Guinean zone respectively where more than two thirds of beeplants identified were cultivated. These results are also similar to those of Lobreau-Callen and Damblon [3] in the vegetation of tropical West Africa and of Ricciardelli D'Albore [35] in the Mediterranean zone. The predominance of spontaneous plants indicates that the Chadian environment is less anthropised whereas the population density and endogenous knowledge plays an important role in the management of beeplants. According to Lobreau-Callen and Damblon [3], the various races of Apis mellifera living in disturbed habitats, cleared, cultivated, highly anthropised area were perfectly capable for adapting to the deforested areas and crops replacing forest. In the North African regions, plantations of Eucalyptus, Citrus, Malus and Prunus orchards substituted the spontaneous flora. However, Lobreau-Callen and Damblon [3] conclude that in mosaic regions where patches of forest were kept close 
to the fields, the bees exploit preferably spontaneous flora. It seems that the behavior of bees is correlated to the structure of vegetation.

\section{Conclusion}

From our research, the region of Guera presents a rich melliferous flora. A total of 52 plants distributed into 16 families and fourth biological types were listed. The most represented family was Mimosaceae. Trees and shrubs were the most abundant biological types confirming the woody clear savanna vegetation type. The most notice flower color was white. The predominance of spontaneous plants indicates that the Chadian environment is less anthropised. Both bee's product and ethological uses of melliferous plants give an interesting argument for their sustainable management and preservation.

\section{References}

[1] Dongock Nguemo, D., Pinta, J.Y., Ngouo, L.V., Tchoumboue, J. and Zango, P. (2004) Inventaire et identification des plantes mellifères de la zone soudano-guinéenne d'altitude de l'ouest Cameroun. Tropicultura, 22, 139-145.

[2] Bradbear, N. (2011) Le rôle des abeilles dans le développement rural. Produits forestiers non ligneux : Manuel sur la récolte, la transformation et la commercialisation des produits et services dérivés des abeilles. FAO, 248 p.

[3] Lobreau-Callen, D. and Damblon, F. (1994) Spectre pollinique des miels de l’Abeille Apis mellifera L. (Hymenoptera, Apidae) et zone de végétation en Afrique occidentale tropicale et méditerranéenne. Grana, 33, 245-253. http://dx.doi.org/10.1080/00173139409429006

[4] Dongock Nguemo, D., Tchoumboue, J., Youmbi, E., Zapfack, L., Mapongmentsem, P.M. and Tchuenguem Fohouo, F.-N. (2011) Predominant Melliferous Plants of the Western Sudano Guinean Zone of Cameroon. African Journal of Environmental Science and Technology, 5, 443-447.

[5] Dukku, U.H. (2013) Identification of Plants Visited by the Honeybee, Apis mellifera L. in the Sudan Savanna Zone of Northeastern Nigeria. African Journal of Plant Science, 7, 273-284. http://dx.doi.org/10.5897/AJPS2013.1035

[6] Schweitzer, P., Nombré, I., Aidoo, K. and Boussim, I.J. (2013) Plants Used in Traditional Beekeeping in Burkina Faso. Open Journal of Ecology, 3, 354-358. http://dx.doi.org/10.4236/oje.2013.35040

[7] Yédomonhan, H., Houenon, G.J., Akoègninou, A., Adomou, A.C., Tossou, G.M. and van der Maese, N.L.J.G. (2012) The Woody Flora and Its Importance for Honey Production in the Sudano-Guinean Zone in Benin. International Journal of Science and Advanced Technology, 2, 2221-8386.

[8] Lobreau-Callen, D., Darchen, R, and Thomas, A. (1986) Apport de la Palynologie à la connaissance des relations abeilles/plantes en savanes arborées du Togo et du Bénin. Apidologie, 17, 279-306. http://dx.doi.org/10.1051/apido:19860401

[9] Tchuenguem Fohouo, F.N. (1993) Activités des insectes anthophiles et son impact sur le rendement de deux plantes cultivées au Cameroun: Zea mays L. (Graminae) et Arachis hypogaea L. (Papilionaceae). Thèse de Doctorat de 3è Cycle, Université de Yaoundé I, 133 p.

[10] Sawadogo, M. (1993) Contribution à l'étude du cycle des miellées et du cycle Biologique annuel des colonies d'abeilles Apis mellifica L. andansonii Lat. à l’ouest du Burkina Faso. Thèse de doctorat de $3{ }^{\text {ème }}$ cycle, Université de Burkina Faso, 198 p.

[11] Tchuenguem Fohouo, F.N., Ngamo, T., Hentchoya Hemo, J. and Messi, J. (1997) Introduction à l'étude de l'activité d'Apis mellifica L. (Hymenoptera; Apidae) sur les fleurs de Callistemon rigidus R. Br. (Myrtaceae) à Dang (Adamaoua-Cameroun). Cameroon journal of Biochemistry and Biology, 7, 78-85.

[12] Tchuenguem Fohouo, F.N. (2005) Activité de butinage et de pollinisation d'Apis mellifera adansonii Latereille (Hymenoptera: Apidae, Apinae) sur les fleurs des trois plantes à Ngaoundéré (Cameroun): Callistemum rigidus (Myrtaceae), Syzyguim guineensevar.Macrocarpum (Myrtaceae) et vocanga africana (Apocynaceae). Thèse de Doctorat d’Etat, Université de Yaoundé I, 103 p.

[13] Bakenga, M., Bahati, M. and Bolagiki, K. (2000) Inventaire des plantes mellifères de Bukavu et sesenvirons (SudKivu-Est de la République Démocratique du Congo). Tropicultura, 18, 89-93.

[14] Dongock Nguemo, D., Tchoumboue, J., Ricciardelli D’Albore, G., Youmbi, E. and Pinta, Y.J. (2007) Spectrum of Melliferous Plants Used by Apis mellifera adansonii in the Sudano-Guinean Western Highlands of Cameroon. Grana, 46, 123-128. http://dx.doi.org/10.1080/00173130701318459

[15] Dongock Nguemo, D., Mapongmetsem, P.M., Tchuenguem Fohouo, F.-N., Gounhagou, D. and Yougouda, H. (2014) Flower Biology of a Beeplant Vitellaria paradoxa (Sapotaceae) in the Sudano Sahalian Zone of Cameroon. Annals of Experimental Biology, 2, 41-51. 
[16] Akoegninou, M.G., Tossou, H., Yedomonhan, T., Fohounfo, T.H. and Traore, D. (2010) Etude des plantes mellifères de la petite saison des pluies et de quelques aspects du comportement des abeilles au Benin. Annales de Botanique de l'Afrique de l'Ouest, 6, 1-13.

[17] Abdullahi, G., Sule, H., Chimoya, A. and Isah, M.D. (2011) Diversity and Relative Distribution of Honeybees Foraging Plants in Some Selected Reserves in Mubi Region, Sudan Savannah Ecological Zone of Nigeria. Advances in Applied Science Research, 2, 388-395.

[18] Djonwangwe, D., Tchuenguem Fohouo, F.-N., Messi, J. and Brückner, D. (2011) Foraging and Pollination Activities of Apis mellifera adansonii Latreille (Apidae) on Syzygium guineense var. Guineense (Myrtaceae) Flowers at Ngaoundéré (Cameroon). Journal of Animal and Plant Sciences, 10, 1325-1333.

[19] Mbogning, E., Tchoumboue, J., Damesse, F., Sanou, S.M. and Canini, A. (2011) Caractéristiques physico-chimiques des miels de la zone Soudano-guinéenne de l'Ouest et de l'Adamaoua Cameroun. Tropicultura, 29, 168-175.

[20] Ayansola, A.A. and Davies, B.A. (2012) Honeybee Floral Resources in South Western Nigeria. Journal of Biology and Life Science, 3, 127-138. http://dx.doi.org/10.5296/jbls.v3i1.1720

[21] Yedomonhan, H. (2004) Plantes mellifères et miel du Bénin: Cas de la forêt classée de la Lama. Mém. DEA, University of Lomé, Lomé, 65 p.

[22] Mazi, S., Tchuenguem Fohouo, F.-N. and Brückner, D. (2013) Foraging and Pollination Behaviour of Apis mellifera adansonii Latreille (Hymenoptera, Apidae) on Gossypium hirsutum (Malvaceae) Flowers at Dang (Ngaoundéré, Cameroon). Journal of Agricultural Science and Technology, 3, 267-280.

[23] Gadbin, C. (1980) Les plantes butinées par les abeilles au Tchad méridional. Apidologie, 11, 217-254. http://dx.doi.org/10.1051/apido:19800304

[24] Guibert, B. and Kakiang, L. (2011) Agence française de développement. Potentialités et contraintes du développement rural dans la région du Tchad centrale, oriental et méridional, 1-6.

[25] Le Bourgeois, T. and Merlier, H. (1995) Adventrop. Les adventices d’Afrique soudano-sahélienne. CIRAD Editeur, Monpelier, $640 \mathrm{p}$.

[26] Merlier, H. and Montegut, J. (1982) Adventices Tropicales. Flore Aux stades plantules et adultes de 123 espèces africaines ou pantropicales, $490 \mathrm{p}$.

[27] Arbonnier, M. (2009) Arbres, arbustes et lianes des zones sèches d'Afrique de l'Ouest. Troisième Edition Quae, MNHN, $574 \mathrm{p}$.

[28] Sawadogo, M. and Guinko, S. (2001) Détermination des périodes de disponibilité et de pénurie alimentaires pour l'abeille Apis mellifica Adansonii Lat. Dans la région ouest du Burkina Faso. Journal des Sciences, 1, 1-8.

[29] Coulibaly, S., Ouattara, D., Koudegnam, C.M.M. and Kamanzi, K. (2013) Diversité et et configuration de la flore ligneuse autour d'un rucher en zone de transition foret-Savane de la Cote d'Ivoire. European Scientific Journal, 9, 227 239.

[30] Aloma, S. (2000) Etude des facteurs de production de miel dans deux zones écologiques différentes au sud du Togo: les sites d'Aképé et d'Agotimé-Nyitoé. Mémoire de DEA, University of Benin, Cotonou, 36 p.

[31] Gumbert, A. (2000) Color Choices by Bumble Bees (Bombus terrestris) Innate Preferences and Generalization after Learning. Behavioral Ecology and Sociobiology, 48, 36-43. http://dx.doi.org/10.1007/s002650000213

[32] Mbofung, G., Tchuenguem Fohouo, F.-N., Boubar, O., Hentchoya Hemo, J. and Brückner, D. (2000) Characterization of Some Honeys from the Adamawa, Cameroon Using Melissopalynological Methods. Biosciences Proceeding, 7, 108-120.

[33] Fægri, K. and van der Pijl, L. (1980) The Principles of Pollination Ecology. 3rd Edition, Pergamon, Oxford.

[34] Pankiew, P. (1967) Study of Honeybee Preference and Behaviour on Normal and Standardlessalfa Flowers. Journal of Apicultural Research, 6, 105-112. http://dx.doi.org/10.1080/00218839.1967.11100167

[35] Ricciardelli D’Albore, G. (1998) Mediterranean Melissopalynology. Università degli di Perugia. Facoltà di Agraria. Istituto di Entomologia agraria, 466 p. 
Submit or recommend next manuscript to OALib Journal and we will provide best service for you:

- Publication frequency: Monthly

- 9 subject areas of science, technology and medicine

- Fair and rigorous peer-review system

- Fast publication process

- Article promotion in various social networking sites (LinkedIn, Facebook, Twitter, etc.)

- Maximum dissemination of your research work

Submit Your Paper Online: Click Here to Submit

Contact Us: service@oalib.com 